\title{
Ecology and nutrition of the large agglutinated foraminiferan Bathysiphon capillare in the bathyal NE Atlantic: distribution within the sediment profile and lipid biomarker composition
}

\author{
Andrew J. Gooday ${ }^{1, *}$, David W. Pond ${ }^{1}$, Samuel S. Bowser ${ }^{2}$ \\ ${ }^{1}$ Southampton Oceanography Centre, Empress Dock, Southampton SO14 3ZH, United Kingdom \\ ${ }^{2}$ Wadsworth Center, New York State Department of Health, PO Box 509, Albany, New York 12201-0509, USA
}

\begin{abstract}
The large agglutinated foraminiferan Bathysiphon capillare de Folin (Protista) was an important component of the macrofauna in box core samples recovered at a $950 \mathrm{~m}$ site on the southern flank of the Wyville-Thomson Ridge, northern Rockall Trough. The long, narrow, very smooth, flexible tubes of $B$. capillare reached a maximum length of almost $10 \mathrm{~cm}$. Densities ranged from 100 to 172 ind. $\mathrm{m}^{-2}$, a figure that represents at least 5 to $9 \%$ of metazoan macrofaunal densities. This infaunal species usually adopted a more or less horizontal orientation within the upper $5 \mathrm{~cm}$ layer of brownish sandy silt. Its cytoplasm yielded a diverse spectrum of fatty acids. These included various monounsaturated fatty acids (39\% of total), mainly 18:1(n-7), 20:1(n-9) and 22:1(n-7), the polyunsaturated fatty acids (PUFA) 20:4(n-6), 20.5(n-3) and 22.6(n-3), and non-methylene diene-interrupted fatty acids (NMIDS), particularly 22:2 $\Delta 7,13$ and 22:2 $\Delta 7,15$. The spectrum of PUFAs is consistent with the ingestion by $B$. capillare of phytodetrital material. However, the presence of NMIDS, reported here for the first time in a protist, provides evidence for a substantial bacterial component in the diet. Viewed by scanning electron microscopy (SEM), the cytoplasm occupied a narrow space between the inner organic test lining and an inner core of detritus around which it formed a sheath. The core material included numerous spherical structures (2 to $10 \mu \mathrm{m}$ diameter) that we interpret as stercomata (waste pellets composed largely of mineral grains). Taken together, our observations suggest that $B$. capillare is a deposit feeder, consuming sediment, detritus and associated bacteria. Other deep infaunal foraminiferans probably have a similar diet, leading us to speculate that these protists, which are often abundant in dysoxic settings, may contribute significantly to carbon cycling in the deep sea. Since B. capillare and similar large Bathysiphon species can be recovered in good condition from bathyal depths, they may prove to be ideal experimental subjects for addressing some fundamental issues in the lipid biochemistry of deep-sea benthic organisms.
\end{abstract}

KEY WORDS: Deep sea $\cdot$ Diets $\cdot$ Fatty acids $\cdot$ Foraminiferans $\cdot$ Lipids $\cdot$ Macrofauna $\cdot$ NMIDS $\cdot$ PUFA

\section{INTRODUCTION}

Most species of foraminiferans belong to the meiofauna, but in deep-sea settings, these sarcodine protists can also constitute a substantial element of the macrofauna (Hessler \& Jumars 1974, Tendal \& Hessler 1977, Gooday et al. 2001). Delicate, soft-bodied agglutinated taxa such as komokiaceans are extremely

*Email: ang@soc.soton.ac.uk abundant in oligotrophic central oceanic areas. Samples collected on more eutrophic bathyal continental margins often yield numerous large foraminiferans belonging to agglutinated taxa, such as Bathysiphon, Hyperammina, Marsipella and Rhabdammina, which have relatively robust, tubular tests (Gooday 1990, Gooday et al. 1997). These are visually conspicuous epifaunal organisms, often protruding from box core surfaces and sometimes clearly visible to the unaided eye in seafloor photographs or from submersibles (Levin et al. 1991, Gooday et al. 1992a). The ecological 
role of these large foraminiferans is not well understood. However, they are capable of consuming fresh organic matter (Levin et al. 1999) and, in some areas, probably play an important role in the degradation of detritus derived from photosynthetic primary production (Meyer-Reil \& Köster 1991, Moodley et al. 2002). There is evidence that some species undergo a rapid physiological 'reawakening' following periods of dormancy, which is presumably an adaptation to a fluctuating food supply (Linke 1992, Linke et al. 1995). Their tests also help to create habitat structure that can be utilised by other foraminiferans and metazoan meiofauna and macrofauna (Levin 1991).

Much less is known about large agglutinated foraminiferans that live below the sediment/water interface. Infaunal species are rarely reported in deep-sea settings, and virtually no information is available regarding their autecology and role in benthic ecosystems. During RRS 'Discovery' Cruise 248 (Bett et al. 2001), we obtained box core and multicore samples at water depths of approximately $950 \mathrm{~m}$ in the northern Rockall Trough, immediately to the south of the WyvilleThomson Ridge. Large agglutinated foraminiferans were sampled in this area during the 'Lightning' and 'Porcupine' expeditions of 1867 to 1868, the earliest serious attempts to investigate life in the deep ocean (Carpenter 1868, Carpenter et al. 1870, Rice 1986). By far the most abundant large agglutinated species present in core samples from this site was Bathysiphon capillare de Folin 1886. A redescription of this poorly known species was given by Gooday (1988) and its wall structure was investigated by Gooday \& Claugher (1989).

The present paper aims to clarify possible roles of Bathysiphon capillare in deep-sea food webs. We address several specific questions: (1) Where does this long tubular species live in relation to the sediment/ water interface? (2) How abundant is it compared to the metazoan macrofauna? (3) How important are food sources such as bacteria and phytodetritus in its diet? Fatty acid analyses are a central feature of our study. This approach has been used for some years to investigate the diets of planktonic, benthic and nektobenthic marine animals (Sargent et. al. 1987, Graeve et al. 1997, Pond et al. 1997b, 1998). Recently, Moodley et al. (2000, 2002) analysed ${ }^{13} \mathrm{C}$ enrichment of selected polar lipid-derived fatty acids (PLFA) in an experimental study of algal carbon uptake by benthic foraminiferans. However, ours is the first comprehensive attempt to analyse lipids in a foraminiferan species. Together with stable isotope experiments (Levin et al. 1999, Moodley et al. 2000, 2002), this method has considerable potential for clarifying the role of foraminiferans, numerically one of the most important of benthic taxa, in deep-sea food webs (Gooday et al. 1992b).

\section{MATERIALS AND METHODS}

The study site. The study area is characterised by an extensive field of low ( $5 \mathrm{~m}$ elevation) carbonate mounds (the 'Darwin Mounds'), discovered in 1998 during an environmental survey of part of the UK continental margin (Bett 1999, Bett et al. 2001, Masson et al. in press). Photographs taken using the WASP (WideAngle Survey Photography) vehicle revealed sparse patches of the deep-water coral Lophelia pertusa and other suspension-feeding organisms on the mounds. Most of the mound area, however, was composed of quartz sands rather than biogenic material. The large xenophyophore Syringammina fragilissima Brady, first described by Brady (1883) on the basis of material collected during the 'Triton' expedition, was conspicuous on the seafloor in certain areas (Bett et al. 1999, Roberts et al. 2000). Mean water temperatures around the Darwin Mounds range from 7.5 to $8.5^{\circ} \mathrm{C}$ and salinity is approximately 35.0 to $35.2 \%$ (Holliday et al. 2000).

The Darwin Mounds area is underlain by a contourite sand sheet deposited under the influence of a bottom current. Near-bottom flows are strongly tidal with maximum velocities of 34 to $35 \mathrm{~m} \mathrm{~s}^{-1}$ being recorded over a 20 d period in July 2000 (Masson et al. in press). Many sediment areas imaged using the WASP system were rippled. Cores with Bathysiphon comprised approximately $10 \mathrm{~cm}$ of sandy silt overlying sticky mud. Surficial sediment from a multicore (13816\#4) was dominated by particles $>63 \mu \mathrm{m}$; the 63 to $125 \mu \mathrm{m}$ fraction yielded $66 \%$ and the 125 to $300 \mu \mathrm{m}$ fraction yielded $0.6 \%$ of the sediment mass. The total organic carbon content of the sediment was low (0.1 to $0.2 \%$; K. Kiriakoulakis pers. comm.). Fresh, undegraded lipids occurred in highest concentrations at a depth of 5 to $6 \mathrm{~cm}$ within the sediment on the mounds and their associated tails (Kiriakoulakis et al. 2000). This probably reflects bioturbation and suggests that the sediments were oxygenated to at least this level. At the control sites, however, lipids were concentrated at the sediment surface (Kiriakoulakis et al. 2000).

Sample collection and processing. Samples were collected close to the carbonate mounds using an undivided USNEL box corer (surface area $0.25 \mathrm{~m}^{2}$ ) and a Barnett-Watson multiple corer equipped with 12 core tubes, each $57 \mathrm{~mm}$ internal diameter (surface area $25.5 \mathrm{~cm}^{2}$ ) (Barnett et al. 1984) (Table 1). Four complete box cores $(13834 \# 2 ; 13840 \# 1 ; 13842 \# 3 ;$ 13842\#4; total surface area $1 \mathrm{~m}^{2}$ ) were carefully dissected using a small knife and a spatula, and all Bathysiphon specimens encountered were documented before being extracted and fixed in $10 \%$ borax-buffered formalin. Some individuals were photographed in situ using an Olympus D450 digital camera before being picked out. Additional specimens were obtained from other cores, 
Table 1. Positions of box core (BC) and multicorer (MC) samples examined for this study. In 'Remarks', the numbers of specimens of large agglutinated foraminifera species removed are indicated in parentheses. Macrofaunal densities (see text) are from Hepburn (2001)

\begin{tabular}{|c|c|c|c|c|c|c|}
\hline Stn and series & Gear & $\begin{array}{l}\text { Latitude } \\
\left({ }^{\circ} \mathrm{N}\right)\end{array}$ & $\begin{array}{l}\text { Longitude } \\
\left({ }^{\circ} \mathrm{W}\right)\end{array}$ & $\begin{array}{l}\text { Depth } \\
\text { (m) }\end{array}$ & Location & Remarks \\
\hline 13816\#1 & $\mathrm{BC}$ & $58^{\circ} 48.83^{\prime}$ & $7^{\circ} 22.73^{\prime}$ & 946 & Tail of mound & Macrofaunal densities \\
\hline $13816 \# 3$ & $\mathrm{BC}$ & $58^{\circ} 48.85^{\prime}$ & $7^{\circ} 22.71^{\prime}$ & 946 & Tail of mound & Macrofaunal densities \\
\hline 13816\#4 & $\mathrm{MC}$ & $59^{\circ} 48.85^{\prime}$ & $7^{\circ} 22.68^{\prime}$ & 947 & Tail of mound & Granulometric analysis \\
\hline $13821 \# 2$ & $\mathrm{BC}$ & $58^{\circ} 48.76^{\prime}$ & $7^{\circ} 21.67^{\prime}$ & 960 & Mound & Macrofaunal densities \\
\hline $13826 \# 2$ & $\mathrm{BC}$ & $59^{\circ} 48.82^{\prime}$ & $7^{\circ} 22.60^{\prime}$ & 948 & Tail of mound & $\begin{array}{l}\text { Macrofaunal densities. } \\
\text { Selected specimens of } \\
\text { Bathysiphon capillare; } \\
\text { also Astrorhiza arenaria } \\
\text { (1), Rhabdammina } \\
\text { abyssorum (2) }\end{array}$ \\
\hline $13826 \# 3$ & $\mathrm{BC}$ & $59^{\circ} 48.82^{\prime}$ & $7^{\circ} 22.57^{\prime}$ & 946 & Tail of mound & Macrofaunal densities \\
\hline $13827 \# 1$ & $\mathrm{BC}$ & $59^{\circ} 48.95^{\prime}$ & $7^{\circ} 22.52^{\prime}$ & 948 & Tail of mound & $\begin{array}{l}\text { Selected specimens of } \\
\text { B. capillare retained }\end{array}$ \\
\hline 13834\#2 & $\mathrm{BC}$ & $59^{\circ} 49.09^{\prime}$ & $7^{\circ} 21.49^{\prime}$ & 958 & Background & $\begin{array}{l}\text { All specimens of } B \text {. } \\
\text { capillare (26) removed }\end{array}$ \\
\hline 13835\#1 & $\mathrm{MC}$ & $59^{\circ} 36.01^{\prime}$ & $7^{\circ} 41.86^{\prime}$ & 904 & $\begin{array}{l}\text { Pockmark area, } \\
\text { sandy sediments }\end{array}$ & $\begin{array}{l}\text { No large agglutinated } \\
\text { foraminifera }\end{array}$ \\
\hline $13835 \# 2$ & $\mathrm{MC}$ & $59^{\circ} 36.00^{\prime}$ & $7^{\circ} 41.86^{\prime}$ & 905 & $\begin{array}{l}\text { Pockmark area, } \\
\text { muddy sediments }\end{array}$ & $\begin{array}{l}12 \text { MCs yielding: } \\
\text { A. arenaria (11), } \\
\text { R. discreta (3), } \\
\text { Pelosina sp. (4) }\end{array}$ \\
\hline 13840\#1 & $\mathrm{BC}$ & $59^{\circ} 49.09^{\prime}$ & $7^{\circ} 21.51^{\prime}$ & 958 & Background & $\begin{array}{l}\text { All specimens of } \\
\text { B. capillare (43) } \\
\text { removed }\end{array}$ \\
\hline $13842 \# 3$ & $\mathrm{BC}$ & $59^{\circ} 49.08^{\prime}$ & $7^{\circ} 21.51^{\prime}$ & 961 & Background & $\begin{array}{l}\text { All specimens of } \\
\text { B. capillare }(25), \\
R . \text { abyssorum }(2) \\
\text { removed }\end{array}$ \\
\hline $13842 \# 4$ & $\mathrm{BC}$ & $59^{\circ} 49.08^{\prime}$ & $7^{\circ} 21.50^{\prime}$ & 959 & Background & $\begin{array}{l}\text { All specimens of } \\
\text { B. capillare (35), } \\
\text { A. arenaria (3) } \\
\text { removed }\end{array}$ \\
\hline
\end{tabular}

being picked either directly from the core or from sieved residues (>250 $\mathrm{mm}$ fraction) (Table 1). Fixed specimens were used for a variety of purposes, including length measurements, and comparison with previously collected material. Specimens for scanning electron microscopy (SEM) were picked as soon as practical, and processed as described in Bowser \& Travis (2000). After critical point-drying, they were mounted on stubs using carbon tape and viewed, either directly or after sputter coating with gold, using a LEO 1550VP FESEM.

Lipid analyses. Specimens of Bathysiphon capillare for lipid analysis (5 replicates of 8 specimens) were removed from box core 13840\#1, as described above, and stored in chloroform:methanol (2:1, v/v) until analysis. Total lipid was extracted following Folch et al. (1957) and subsequently transesterified in methanol containing $1.5 \%$ sulphuric acid at $50^{\circ} \mathrm{C}$ for $16 \mathrm{~h}$ to gen- erate fatty acid methyl esters (FAME; Christie 1982). FAMEs were then purified by thin layer chromatography using a hexane:diethyl ether:acetic acid (90:10:1, v/v/v) solvent system. Purified FAMEs were dissolved in hexane to a concentration of $2 \mathrm{mg} \mathrm{ml}^{-1}$ and analysed by gas chromatography on a Carlo Erba (Trace 2000 series) fitted with a ZBWAX fused silica capillary column $(30 \times 0.32 \mathrm{~mm}$ internal diameter $)$ using hydrogen as the carrier gas. Fatty acids were identified using the procedures detailed in Pond et al. (1998).

\section{RESULTS}

\section{The test of Bathysiphon capillare and its contents}

A total of 129 intact specimens of Bathysiphon capillare picked from the 4 carefully dissected box cores 
were between 8 and $68 \mathrm{~mm}$ (mean $34.8 \mathrm{~mm}$, SD $15.2 \mathrm{~mm}$ ) long and 180 to $540 \mu \mathrm{m}$ (wider end) and 140 to $480 \mu \mathrm{m}$ (narrower end) in width. The 2 largest individuals (selected specimens from box core 13827\#1) were 105 and $95 \mathrm{~mm}$ long, tapering in width from 600 to 440 and 640 to $420 \mu \mathrm{m}$, respectively. The tube usually follows a curved, sometimes sinuous course and the apertural end is constricted. The test surface is white, very smooth, with a variably developed, silvery reflective sheen. Examination by SEM (Fig. 1A,B) confirmed that the wall structure of Bathysiphon capillare comprises a very thin, outer layer of imbricated, micaceous grains underlain by a much thicker, loose aggregate of mixed composition (Gooday \& Claugher 1989).

In some dried specimens, the agglutinated wall was easily teased away. SEM of such preparations revealed that the test was occupied by a dense core of granular material surrounded by a thin, tubular sheath of cytoplasm (Fig. 1C). In certain areas, this cytoplasmic sheath merged into typical reticulopodia which encircled the detrital core (not illustrated) or ramified along the lumenal (i.e. inner) face of the inner organic lining of the test (Fig. 1E,F). Visible on broken surfaces of the core material (Figs. 1D \& 2A,B) were a number of identifiable particles including sponge spicules, occasional coccoliths, and parts of crustacean appendages (not illustrated). The most numerous structures, however, were more or less spherical bodies, 2 to $10 \mu \mathrm{m}$ in diameter, with a surface texture that was rough and uneven at high magnifications (Figs. 1D \& 2C,D). Preliminary X-ray microanalysis revealed peaks for $\mathrm{Al}, \mathrm{Si}$ and $O$, suggesting the presence of mineral grains, and $\mathrm{C}, \mathrm{N}$, and $\mathrm{P}$, suggesting the presence of an organic component. We interpret these structures as stercomata, pellets of waste material that are present in large numbers in certain foraminiferans, for example, komokiaceans (e.g. Cartwright et al.1989). They probably represent the consolidated remains of ingested, finegrained sedimentary material. Cytoplasmic structures were not visible within the granular contents of the tube, which therefore appear to be extracellular. However, branching reticulopodia were clearly evident on the inner surfaces of the inner organic lining of the test (Fig. 1E). One of the reticulopodia gave rise to a food cup closing around what appeared to be a bacterium (Fig. 1F).

\section{Abundance and distribution within the sediment}

Specimens recovered from the 4 systematically studied box-cores were all filled with the dark greenishbrown, granular material described above. Those examined by SEM had pseudopodia. All specimens were therefore presumed to be alive when captured.
Tubes of Bathysiphon capillare are fragile, but since these specimens were carefully excavated from the sediment, we regard them as intact individuals. The number in each core was 26 (13834\#2), 43 (13840\#1), 25 (13842\#3) and 35 (13842\#4), corresponding to a density of 104, 172, 100 and 135 ind. $\mathrm{m}^{-2}$. Additional data on the abundance of Bathysiphon capillare in the northern Rockall Trough were obtained from box-cores sieved for macrofauna (L. Hepburn \& J. D. Gage unpubl.). The 0 to $10 \mathrm{~cm}$ layer (>500 $\mu \mathrm{m}$ fraction) of 3 undisturbed cores (13816\#1, 13816\#3 and 13826\#3) from the Darwin Mounds area yielded 11, 57 and 23 specimens, respectively, of this species, while a core from a nearby mound field (13821\#2) contained 57 specimens. Most of these tubes were obvious fragments and their densities cannot be compared directly to those of intact individuals.

Bathysiphon capillare occurred at all depths in the sediment down to about $50 \mathrm{~mm}$, but most specimens were observed between 15 and $40 \mathrm{~mm}$ below the surface (Fig. 3). Three individuals from box core 13842\#4 protruded from the surface. The other 126 specimens from the 4 systematically examined cores occurred below the sediment surface within a $5 \mathrm{~cm}$ layer of brownish sand (Fig. 4A,B). The tubes were not observed within the underlying greyish sand (5 to $10 \mathrm{~cm}$ depth) or in the dense mud that occupied the lower part of the core (>10 cm depth). The orientation of the tubes was usually approximately horizontal but occasional specimens curved downwards at one end, usually the broader one. Their lateral distribution within the $5 \mathrm{~cm}$ thick layer of brownish sand was fairly even, although paired individuals sometimes occurred (Fig. 4C). Specimens were never observed to be associated with burrows or biogenic structures. Bathysiphon tubes also occurred infaunally in cores that were not studied systematically.

The only other large agglutinated foraminiferans present in the 4 carefully dissected box-cores were occasional ( $\mathrm{n} \leq 3$ per core) triradiate specimens of Rhabdammina abyssorum Sars, and its biradiate variant 'Rhabdammina discreta', tubes of which sometimes protruded from the sediment surface. In addition, 3 specimens of Astrorhiza arenaria lay flat on the surfaces of 2 box-cores (13842\#4 and 13826\#2) from the main Darwin Mounds study area. Both these species, and particularly $R$. abyssorum, are often fairly common in the sieved residues $(>500 \mu \mathrm{m})$ of boxcores obtained in this area, although fragmentation during sieving made quantification impossible. Other large agglutinated species encountered as fragments in these samples were Hyperammina laevigata, $H$. fragilis (both at Stn 13821\#2) and Technitella legumen (13826\#2). 

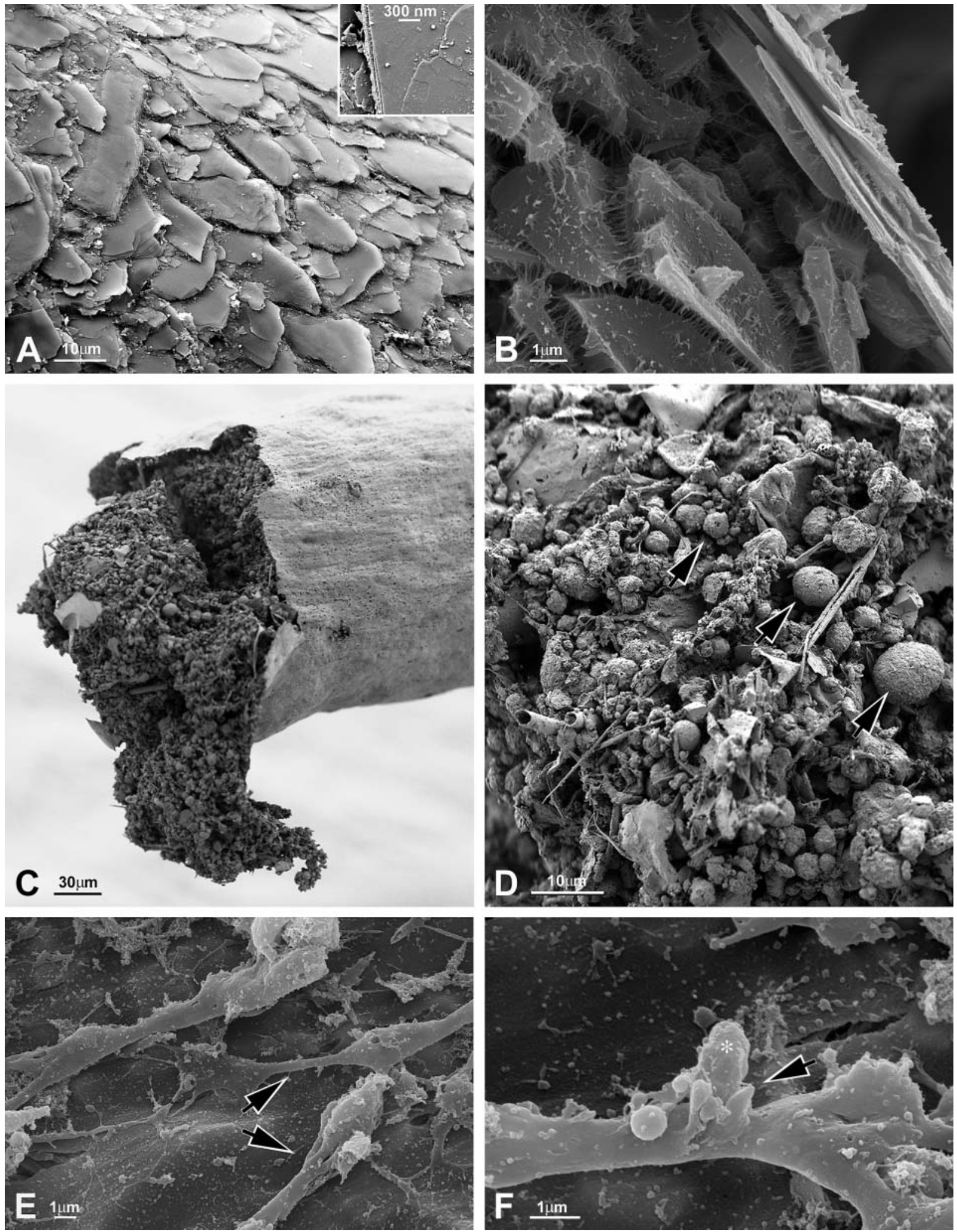

Fig. 1. Scanning electron micrographs of Bathysiphon capillare. (A) Outer surface of test consisting of imbricated, plate-like mineral grains that give the test surface a very smooth finish on a scale of $\mu \mathrm{m}$. Inset shows mica-like cleavage pattern of the outer grains. (B) Broken surface of wall showing thin, surface layer of micaceous grains and underlying grains held together by cobweb-like strands of organic cement. (C) Granular contents of tube bounded by a thin sheath of cytoplasm. (D) Detailed view of granular contents, showing stercomata (arrowed), detrital grains, sponge spicules and other debris indicative of deposit feeding. (E) Branching reticulopodia (arrowed) attached to lumenal (inner) aspect of inner organic lining. (F) Detail of reticulopod giving rise to a food cup engulfing what appears to be a bacterium $(*)$ 

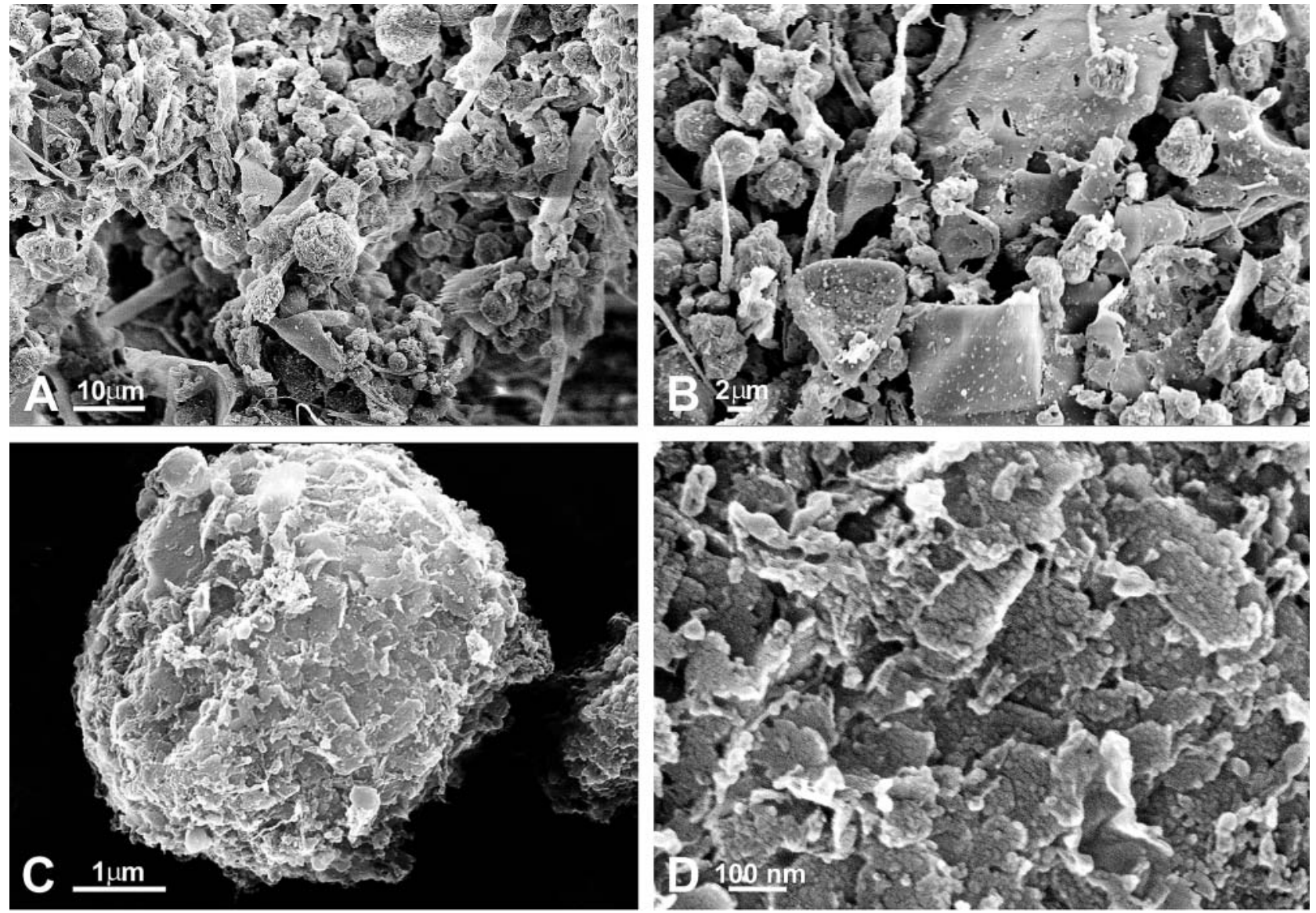

Fig. 2. Scanning electron micrographs of Bathysiphon capillare. $(\mathrm{A}, \mathrm{B})$ Details of granular material that fills lumen of tube. Among the particles present are stercomata and sponge spicules. (C) Single stercome. (D) Surface of stercome showing tiny constituent grains

Fatty acid composition

Bathysiphon capillare contained a diverse spectrum of fatty acids, which were dominated by monounsaturated fatty acids $(\sim 39 \%$ of the total, Fig. 5). These monenoic fatty acids comprised mostly 18:1(n-7), 20:1(n-9) and 22:1(n-7) with lesser amounts of 16:1(n-9), 18:1(n-9) and 20:1(n-7). Percentages of total saturated, diunsaturated and polyunsaturated fatty acid (PUFA) were similar, ranging from 18 to $22 \%$. Non-methylene diene interrupted fatty acids (NMIDs) were present in substan-

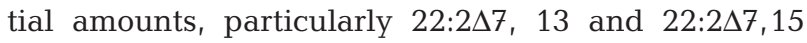
(Fig. 5). The single most abundant fatty acid in B. capillare was $20: 4(n-6)$ which accounted for $16 \%$ of total fatty acids, while the long chain PUFA of the $n-3$ series, i.e. 20:5(n-3) and 22:6(n-3), were present in much lower amounts $(\sim 1$ and $4 \%$, respectively).

\section{DISCUSSION}

Bathysiphon capillare has been reported previously from bathyal localities in the tropical and temperate NE Atlantic (off NW Africa, the Iberian margin, the Bay of Biscay, Porcupine Seabight, Rockall Trough and Norwegian fjords) (Gooday 1988, Schiebel 1992, Timm 1992, Bender 1995, Schönfeld 2001). Many of the records are from water depths of 800 to $1200 \mathrm{~m}$. The only previous Rockall Trough record is from 'Gold-

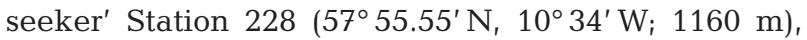
although reports of Bathysiphon filiformis from the warm-water area to the south of the Wyville-Thomson Ridge (Pearcey 1890, Murray \& Taplin 1984) probably refer to B. capillare. Some individuals (a fifth of all those carefully collected) from the Darwin Mounds were $>50 \mathrm{~mm}$ in length (in 1 case $105 \mathrm{~mm}$ ), compared to the lengths of 10 to $20 \mathrm{~mm}$ reported in earlier studies (Gooday 1988). This probably reflects the fact that 


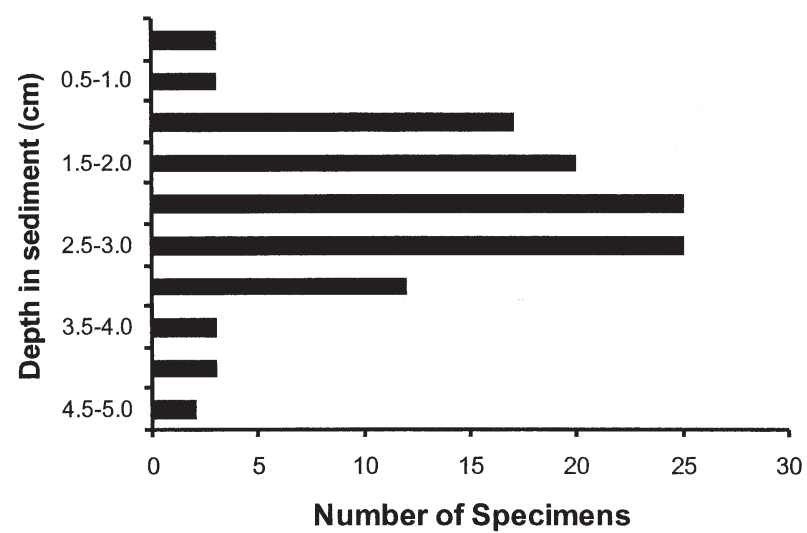

Fig. 3. Vertical distribution of Bathysiphon capillare within the sediment profile. Data are based on pooled data from 4 carefully excavated box cores $(13834 \# 2,13840 \# 1,13842 \# 3$ and 13842\#4)

earlier material was collected using towed gear (dredge or epibenthic sledge) and therefore subjected to considerable fragmentation. In other respects, the new material resembles the description of $B$. capillare given by previous authors (de Folin 1886, Gooday 1988).
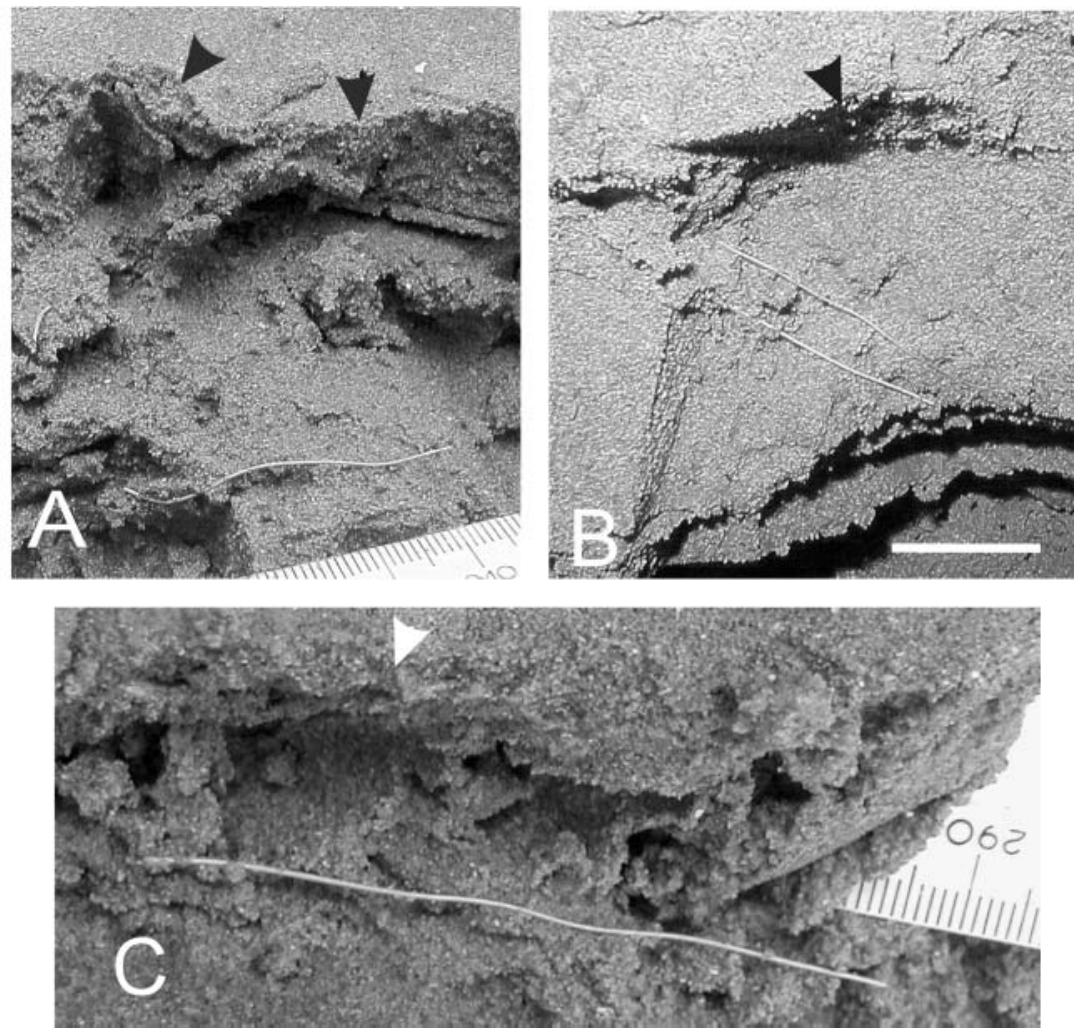

Fig. 4. Bathysiphon capillare. (A,C) Individuals of Bathysiphon capillare photographed in situ in box cores from the Darwin Mounds area. The specimens have been revealed by carefully excavating away the surrounding sediment; the arrowheads indicate the edge of the undisturbed sediment surface. (B) Two individuals lying side by side in an excavated box core; scale bar is $2 \mathrm{~cm}$
The relative scarcity of large agglutinated foraminiferans in cores from the Darwin Mounds area is surprising given the abundance of such forms in samples obtained during early oceanographic expeditions (e.g. 'Lightning', 'Porcupine' and 'Triton'). For example, Brady (1882) reported that a sample from his 'Triton' Stn D, located close to our study area $\left(59^{\circ} 37^{\prime} \mathrm{N}, 7^{\circ} 19^{\prime} \mathrm{W}\right.$, water depth 530 fathoms $=970 \mathrm{~m}$ ), was very rich in taxa such as $A s$ trorhiza, Rhabdammina and Marsipella. This difference presumably reflects the use by the Victorian naturalists of a dredge. Dredges and other towed gears can yield huge numbers of large foraminiferal specimens because they concentrate individuals from a wide tract of seafloor that may encompass different sedimentary habitats and faunal patches (Bandy \& Rodolfo 1964, Herb 1971). In fact, 1 of the species reported by Brady (1882), Astrorhiza arenaria, was common (11 complete individuals in 12 cores, total surface area $306 \mathrm{~cm}^{2}$ ) in muddy sediments recovered during 1 deployment of the multicorer (13835\#2) in an area close to the Darwin Mounds, characterised by pockmark-like features (Bett et al. 2001). Another complete set of multicorer samples (13835\#1) obtained approximately $100 \mathrm{~m}$ away yielded sandy sediments devoid of large agglutinated foraminiferans, suggesting that the distribution of $A$. arenaria on the seafloor is distinctly patchy.

Fossil Bathysiphon are reported from deep-water turbidite ('flysch') deposits in many parts of the world (e.g. Miller 1988, 1995). The tubes of these large, robust species had been transported by turbidity currents and deposited in basinal settings. In contrast, all specimens of Bathysiphon capillare that we examined contained a core of dark granular material and appeared to be intact. Their delicate tests are very unlikely to have survived transport by a turbidity current without severe damage. There is no evidence for turbidite deposits in our study area, which is underlain by a sandy contourite deposit. Although current speeds of up to $35 \mathrm{~cm}$ $\mathrm{s}^{-1}$ have been recorded in the area, and the sandy sediment surface is rippled (Masson et al. in press), there is no evidence that $B$. capillare and other faunal elements are anything other than indigenous.

\section{Contribution to macrofaunal densities}

The invertebrate fauna in the area of the Darwin Mounds is generally sparse. Few macrofauna were observed, either 


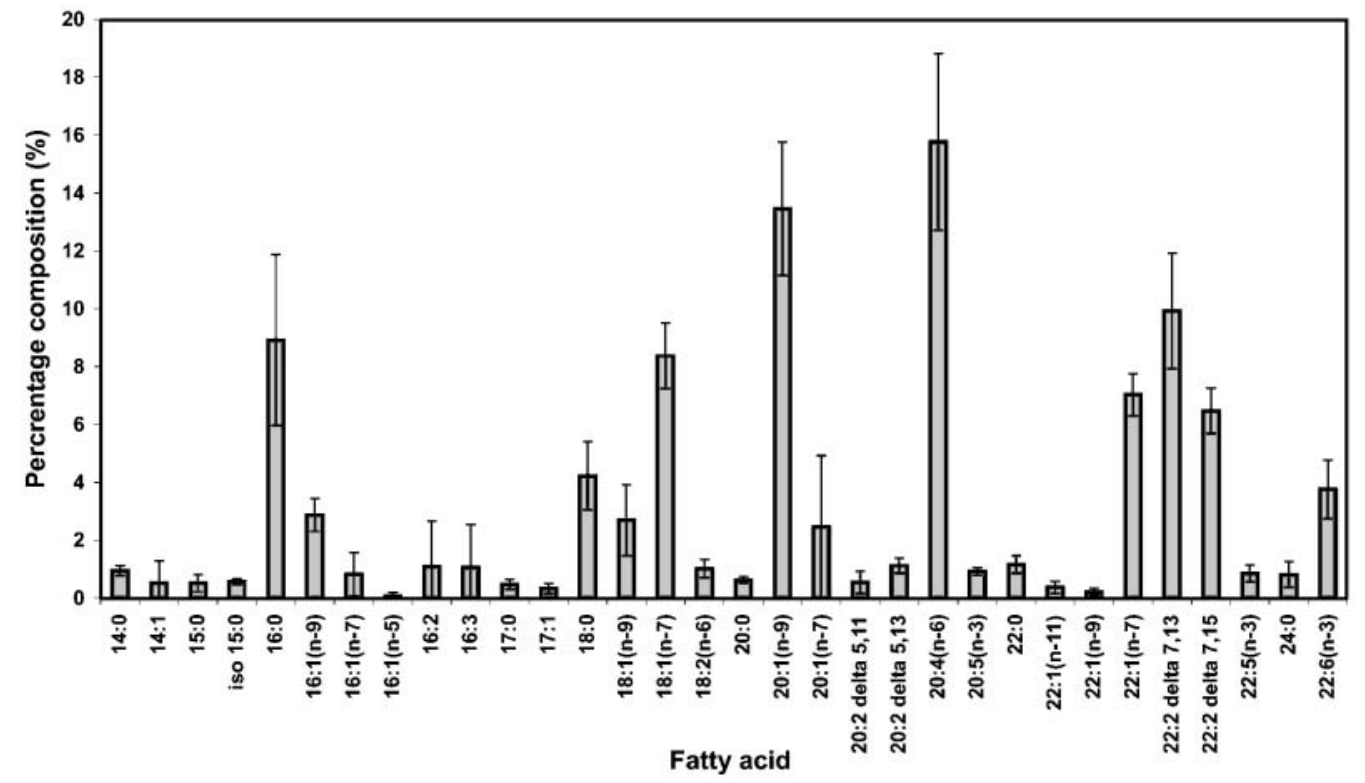

Fig. 5. Fatty acid composition of Bathysiphon capillare. Data are from box core $13840 \# 1(n=5$, SE bars are indicated on the figure) on the sediment surface or within the cores, although small ophiuroids were quite common. Hepburn (2001) reports the following density values (ind. core $^{-1}$; $>500 \mu \mathrm{m}$ fraction) for metazoan macrofaunal taxa in 5 undisturbed box-cores collected around the Darwin mounds during the 'Discovery' cruise 248: Stn 13816\#1, 233 ind. core $^{-1} ;$ Stn 13816\#3, 269 ind. core $^{-1} ;$ 13821\#2, 279 ind. core $^{-1} ; 13826 \# 2,112$ ind. core $^{-1} ; 13826 \# 3$, 261 ind. core $^{-1}$; mean density value, 233 ind. core $^{-1}$ $\left(=932\right.$ ind $\left.\mathrm{m}^{-2}\right)$. The core from Stn 13821 was located on a mound; the other cores were obtained from the tails of mounds. Densities of Bathysiphon capillare (100 to 172 ind. $\mathrm{m}^{-2}$ ) represent 10.7 to $18.5 \%$ of the mean metazoan macrofaunal density in these 5 cores.

Recent work on the UK continental margin comparing macrofauna (>500 $\mu \mathrm{m})$ in box-cores and in cores recovered using a hydraulically damped megacorer (a larger version of the multicorer) suggests that boxcorers underestimate macrofaunal densities by a mean factor of about 2.1 (Bett unpubl.). This, presumably, is because lighter-bodied, surface-dwelling organisms are blown away by the bow wave generated by the box-corer. Applying this factor to the mean macrofaunal density value of Hepburn (2001) gives a figure of 1957 ind. $\mathrm{m}^{-2}$. Megacorer samples collected over the depth range from 706 to $1098 \mathrm{~m}$ in the northern Rockall Trough during the Atlantic Margin Environmental Survey (RRS 'Charles Darwin' Cruise 112C) yielded 1317 to 4841 (mean 2333) macrofaunal ind. $\mathrm{m}^{-2}$. ${ }^{1}$ The

${ }^{1}$ Bett BJ (2000) Benthic ecology of the Faroe-Shetland channel. In: Environmental surveys of the seafloor of the UK Atlantic Margin, Atlantic Frontier Environmental Network (CD-ROM), section 4.3.2 (available from Geotek, Daventry, Northhants NN11 5EA, UK) values for the 2 stations closest to the Darwin Mounds area (1BA5 and 1BA6) were 1825 and 3095 (mean 2460) ind. $\mathrm{m}^{-2}$. If we assume a value of around 2000 ind. $\mathrm{m}^{-2}$ for metazoan macrofauna in the Darwin mounds area, then Bathysiphon capillare densities (100 to 172 ind. $\mathrm{m}^{-2}$ ) are equivalent to about 5 to $9 \%$ of macrofaunal densities. This should be considered to be a minimum figure since it assumes that, unlike the metazoan macrofauna, no individuals of $B$. capillare were swept away by the box-corer bow wave. Unfortunately, fragmentation makes it impossible to give accurate densities for the total foraminiferal macrofauna.

\section{Autecology}

Previous field (Christiansen 1971, Gooday et al. 1992a) and laboratory (Hannah \& Rogerson 1997, Gross 1998, 2000, Heinz 1999) observations suggest that some Bathysiphon species protrude above the sediment surface, while others live below the sediment-water interface. At our study site, B. capillare clearly occupies an infaunal microhabitat within the upper $5 \mathrm{~cm}$ of sediment. Since the work of Corliss (1985), the occupancy of infaunal microhabitats by deep-sea benthic foraminiferans has been well documented (reviewed by Jorissen 1999). Most infaunal species are relatively tolerant of low oxygen concentrations, and some occur in sediment layers below the oxic/anoxic boundary (Moodley \& Hess 1992, Bernhard 1993, Jorissen et al. 1998, Bernhard \& Sen Gupta 1999, Schönfeld 2001). Although oxygen data are not available from our study site, B. capillare is clearly associated with the upper brownish layer of relatively loose, sandy sediment that probably contains some 
oxygen. Schönfeld (2001) reported that oxygen levels (measured using a shipboard oxygen microelectrode) reached 0 around $5 \mathrm{~cm}$ sediment depth in 3 cores collected at a similar water depth (800 to $1200 \mathrm{~m}$ ) on the Iberian margin. The 2.5 to $5.0 \mathrm{~cm}$ horizon of one of these cores (from $1085 \mathrm{~m}$ ) yielded 4 specimens of B. capillare, considered by Schönfeld to be an indicator of dysoxic conditions $\left(\mathrm{O}_{2}<0.3 \mathrm{ml} \mathrm{l}^{-1}\right)$. Two small, undescribed Bathysiphon species are fairly common in the core region of the oxygen minimum zone (OMZ) in the NW Arabian Sea (bottom-water oxygen concentration $\sim 0.13 \mathrm{ml} \mathrm{l}^{-1}$ ), confirming that some species of this genus can withstand a substantial degree of oxygen depletion (Gooday et al. 2000).

The very smooth outer surface (Fig. 1A,B) of Bathysiphon capillare tubes might suggest that specimens can move actively through the substrate. Subsurface movement in 'ant farm' aquaria by unidentified Bathysiphon spp. recovered from sublittoral and bathyal sites (water depths from $<100$ to $900 \mathrm{~m}$ ) has been reported by several authors (Hannah \& Rogerson 1997, Gross 1998, 2000, Heinz 1999). Rates of movement ranged from $<2.5$ to $7.3 \mu \mathrm{m} \mathrm{min}{ }^{-1}$. Both Gross (1998) and Heinz (1999) observed that Bathysiphon spp. created smooth-sided burrows, presumably reflecting their smooth test surfaces. However, these mobile species were very small; for example, the individual illustrated by Heinz (1999 Plate 1, Fig. G) was $1.75 \mathrm{~mm}$ long. Due to increased frictional resistance and sediment overburden pressures (Severin \& Erskian 1981, Severin 1987), the much larger (up to $10 \mathrm{~cm}$ long) B. capillare specimens from the Darwin Mounds area are less likely to be mobile. Possibly, these long tubes change their position by growth rather than by active locomotion

\section{Lipid composition}

Insights into the diets and trophic dynamics of foraminiferans and other marine organisms can be obtained from their fatty acid composition (Scott et al. 1999). In the case of foraminiferans, which are unicellular protists and therefore lack guts, these biomarkers will be located either in the contents of food vacuoles or in the lipid inclusions that are sometimes a prominent feature of foraminiferal cytoplasm (e.g. Heeger 1990, Turley et al. 1993). Fatty acids that either lack double bonds (saturated) or include only a single double bond (monounsaturated) tend to be used as storage reserves and are extensively catabolised to generate metabolic energy. These fatty acids can be derived both from dietary sources and/or synthesised de novo by the organism. PUFAs containing 2 or more double bonds are particularly important for marine organisms since they serve crucial functional roles, for example within cell membranes. Many animals, particularly vertebrates, are either unable to produce PUFA or are unable to do so at a sufficient rate to satisfy their growth and reproductive demands. For these organisms, PUFA are 'essential' dietary components. However, it is not known whether PUFA are essential for marine heterotrophic protists. The main sources of PUFA in the marine environment are photosynthetic microplankton; for example, diatoms are rich in 20:5(n-3) and flagellated algae contain high amounts of 22:6(n-3) (Sargent et al. 1987). Thus, in deep-sea ecosystems, PUFAs are useful markers of comparatively undegraded organic phytodetrital material (Fileman et al. 1998).

The abundance of $n-7$ series fatty acids and NMIDs suggests a substantial bacterial component to the diet of Bathysiphon capillare, since (n-7) fatty acids and particularly 18:1(n-7) are abundant in most classes of bacteria (Sargent et al. 1987). The presence of NMIDs in B. capillare is notable since this is the first report of these compounds in a protist. As discussed extensively elsewhere (Ackman \& Hooper 1973, Zhukova 1991, Fang et al. 1993), the production of NMIDs is typical of marine invertebrates that experience high dietary inputs of (n-7) 'bacterial' fatty acids. These compounds are thought to be synthesised first by chain elongation of bacterially produced $18: 1(n-7)$ to $20: 1(n-7)$, followed by $\Delta 5$ desaturation to $20: 2 \Delta 5,13$, and finally by further chain elongation to $22: 2 \Delta 7,15$. The NMIDs $20: 2 \Delta 5,11$ and $22: 2 \Delta 7,13$ are similarly produced, but in this instance, the precursor fatty acid is $18: 1(n-9)$. The function of NMIDs in aquatic organisms is unknown, although they possibly compensate for a low dietary availability of PUFA (Fullarton et al. 1995, Pond et al. 1997a). The high amounts of NMIDs in B. capillare therefore provide evidence of a predominately bacter$\mathrm{ial} /$ detrital diet with minor contributions of undegraded phytodetritus. The infaunal occurrence of this species, and the presence within the test of numerous stercomata-like bodies that probably represent the consolidated remains of ingested sediment (Fig. 1D), are also consistent with a bacterial/detrital diet.

The relatively large amounts of $n-9$ fatty acids, particularly 20:1(n-9), suggest that these fatty acids are synthesised de novo by Bathysiphon capillare, possibly as energy storage compounds. However, 20 and 22 carbon monounstaurated fatty acids are often major components of zooplankton, particularly those that inhabit the deep ocean (Pond et al. 2000), and so a detrital/zooplankton source for these compounds cannot be excluded. The PUFA 20:5(n-3) and 22:6(n-3), which are abundant in photosynthetic microplankton, are likely to derive from phytodetrital material and indicate that labile compounds of photosynthetic origin make some contribution to the diet of $B$. capillare. A 
further possible source of the PUFA is from heterotrophic bacteria, since some strains isolated from the deep sea have been shown to produce these compounds (Russell \& Nichols 1999). Bacteria in sediment samples from the Darwin mounds site, however, contained only very low amounts of PUFA (D. W. Pond et al. unpubl.). Given that other large deep-sea agglutinated foraminiferans have been shown to ingest phytodetrital material (discussed below), it is likely that the majority of 20:5(n-3) and 22:6(n-3) in B. capilliare was ultimately derived from photosynthetic microplankton. However, future research is required to assess the importance of bacterially derived PUFA in deep-sea ecosystems.

The high amount of 20:4(n-6) in Bathysiphon capillare is puzzling. This fatty acid is not particularly abundant in photosynthetic microplankton and unless it is highly conserved by $B$. capillare, phytodetritus is unlikely to be the sole source. A number of deep-sea organisms contain concentrations of 20:4(n-6) (Fullerton et al. 1995, Ginger et al. 2001). Why this should be is not known. More generally, however, it has been suggested that the unsaturated fatty acid composition of cell membranes can affect their fluidity (de Long \& Ayes 1985). Under deep-sea conditions of low temperature and high pressure, 20:4(n-6) may possibly serve a crucial role in maintaining the integrity of cell membranes. The resolution of these issues will require the application of experimental tracer techniques to the study of deep-sea organisms.

\section{Deep-sea foraminiferal diets and implications for carbon cycling}

The evidence from lipid biomarkers is consistent with our relatively sparse knowledge of foraminiferal dietary requirements. The extensive and highly mobile granuloreticulopodial networks of foraminiferans are very efficient food-gathering systems (Travis \& Bowser 1991). Shallow-water species use them to collect and consume various small organisms, mainly pennate diatoms, small chlorophytes and bacteria in addition to yeasts, fungi and even small animals (Lipps \& Valentine 1970, Lee \& Muller 1973, Lee 1980, 1993, Lipps 1983, Rivkin \& DeLaca 1990, Goldstein 1999). Culture studies suggest that feeding is selective (Muller 1975, Moodley et al. 2000) and that some species require bacteria in their diets in order to sustain reproduction (Muller \& Lee 1969). Food acquisition is often very rapid and experimental studies suggest that algal particles are processed within hours of being deposited (Moodley et al. 2000).

Diets in deep-sea foraminiferans are probably broadly similar to those of shallow-water species. They also appear to reflect the preferences of individual spe- cies for particular microhabitats within the sediment profile (Jorissen 1999). Species living at or close to the sediment surface often consume phytodetritus (Gooday et al. 1992b). The cytoplasm of some epifaunal miliolids and rotaliids (calcareous foraminiferans) is reported to contain green algal cells derived from fresh phytodetrital deposits (Gooday \& Turley 1990, Heeger 1990, Gooday et al. 1992b, Altenbach et al. 1993). Experiments and observations of living specimens indicate that large, surface-dwelling agglutinated foraminiferans (e.g. Bathysiphon spp., Cribrostomoides subglobosa, Rhabdammina abyssorum) also ingest substantial quantities of phytodetrital or algal material (Altenbach 1992, Linke 1992, Linke et al. 1995, 1999). It is likely that these larger agglutinated and smaller calcareous species play an important role in the degradation of labile freshly settled phytodetritus in various bathyal and abyssal settings (Gooday 1988, Meyer-Reil \& Köster 1991, Levin et al. 1999, Köster \& Meyer-Reil 2001, Moodley et al. 2002).

Other deep-sea foraminiferans may be less reliant on labile food sources. Komokiaceans and related taxa that accumulate large quantities of stercomata ingest sediment and presumably feed on the associated bacteria (Tendal \& Hessler 1977, Gooday et al. 1997). These stercomata-bearing foraminiferans are characteristic of abyssal, oligotrophic regions, where fresh organic matter is scarce. Deep-infaunal foraminiferans ('Type C' vertical distribution pattern of Jorissen 1999), which are most abundant in high productivity areas, are also likely to be deposit feeders. Their abundance may reflect the availability of relatively non-labile food 'stored' within the sediments (Jorissen et al. 1998, Van der Zwaan et al. 1999). Deep-infaunal foraminiferans are typically associated with oxygen-depleted sediment porewaters, prompting some authors to speculate that, like some ciliates (e.g. Fenchel \& Jansson 1966, Fenchel 1969, 1987, Goulder 1971), they feed on bacteria associated with redox fronts within the sediment (Jannink et al. 1998, Jorissen et al. 1998, Van der Zwaan et al. 1999, Schmiedl et al. 2000, Schönfeld 2001, Fontanier et al. 2002). Direct evidence about diets, however, is scarce and available only for calcareous species. When cultured in the laboratory at $1 \mathrm{~atm}$, 2 deep-infaunal species (Globobulimina spp. and Chilostomella ovoidea) from Sagami Bay, Japan (1450 m water depth) consumed fresh, heat-killed algae (Chlorella) at a much slower rate than epifaunal/shallow infaunal species (Kitazato \& Ohga 1995). Dried Chlorella, on the other hand, was utilised more quickly. Using transmission electron microscopy, Goldstein \& Corliss (1994) investigated the contents of food vacuoles in Uvigerina peregrina and Globobulimina pacifica, shallow- and deep-infaunal species, respectively, collected at a $710 \mathrm{~m}$ site in the San Pedro Basin off 
California. Both contained relatively large quantities of sediment particles, organic detritus and associated bacteria. The San Pedro Basin sediments had a higher organic carbon content (3.0 to $3.5 \%$ ) than the Darwin Mounds sediments and were overlain by oxygendepleted $(<15 \mu \mathrm{M})$ bottom water. Our observations suggest that, despite these environmental differences, Bathysiphon capillare has a similar diet. There is also evidence that it consumes some fresh phytodetritus. In Sagami Bay, 2 other deep-infaunal species (G. affinis and $C$. ovoidea) both exhibited reproductive responses to phytodetritus deposition, and therefore may also be able to utilise labile material as well as more degraded detritus (Kitazato et al. 2000).

These observations have significant implications for carbon cycling. Infaunal foraminiferans are widely distributed in marine environments. They dominate foraminiferal faunas in areas of dysoxic bottom water (Bernhard \& Sen Gupta 1999), but also occur in subsurface sediments overlain by well-oxygenated bottom water (Gooday et al. 2001, Fontanier et al. 2002). We speculate that deep-infaunal species, both agglutinated and calcareous, are deposit (sediment) feeders that consume bacteria and relatively degraded (refractory) detrital material in a variety of settings, and may represent an important route by which these carbon sources are made available to higher trophic levels. Their trophic role probably complements that of surface-dwelling foraminiferans, including large, agglutinated species such as Astrorhiza arenaria and Rhabdammina abyssorum, which are likely to include a higher proportion of fresh phytodetritus in their diets.

\section{CONCLUDING REMARKS}

Bathysiphon capillare was by far the most abundant large agglutinated foraminiferan present in box-cores from a site ( 950 m water depth) at the northern Rockall Trough. This macrofauna-sized protist occurred infaunally within the top $5 \mathrm{~cm}$ of sediment, near the interface between brown (upper) and grey (lower) layers of silty sand. Lipid biomarkers, and the presence within the tubular test of a mass of material including probable stercomata (waste pellets), suggest that it is a deposit feeder, ingesting fine-grained sediment and associated bacteria together with a certain amount of fresher phytodetrial material. As a result, this species and other infaunal foraminiferans may play a significant role in carbon cycling on continental margins. B. capillare can be predictably sampled, and the protection afforded by its test and the surrounding sediment ensures that it can be recovered from the seafloor in good condition. Thus, B. capillare, and perhaps other large Bathysiphon species, such as B. filiformis and B. major (Gooday et al. 1992a), could provide an excellent experimental system, well suited to resolving fundamental issues regarding the lipid biochemistry of deep-sea organisms and hence, carbon pathways in deep-sea food webs.

Acknowledgements. We thank the officers and crew of RRS 'Discovery', Brian Bett and David Billett for their help at sea, and Alan Hughes for his assistance in the preparation of Figs. $1 \& 2$. The paper benefited from the helpful comments of Lisa Levin and 3 anonymous referees. We are grateful to Leanne Hepburn, Murray Gregory and John Gage for providing access to an unpublished MSc thesis on metazoan macrofauna from the Darwin Mounds region. This work was conducted under NERC Grant no. NER/B/S/2000/00269. The Wadsworth Center's electron microscopy core and NSF grant DBI-0116551 in support of its SEM facility are gratefully acknowledged. S.S.B. was supported in part by NSF grant OPP-9725830.

\section{LITERATURE CITED}

Ackman RG, Hooper SN (1973) Non-methylene interrupted fatty acids in lipids of shallow-water marine invertebrates: a comparison of two molluscs (Littorina littorea and Lunatia triseriata). Comp Biochem Physiol B 46:153-165

Altenbach AV (1992) Short term processes and patterns in the foraminiferal response to organic flux rates. Mar Micropaleontol 19:119-129

Altenbach AV, Heeger T, Linke P, Spindler M, Thies A (1993) Miliolinella subrotunda (Montague), a miliolid foraminifer building large detritic tubes for a temporary epibenthic lifestyle. Mar Micropaleontol 20:293-301

Barnett PRO, Watson J, Connelly D (1984) A multiple corer for taking virtually undisturbed samples from shelf, bathyal and abyssal sediments. Oceanol Acta 7:401-408

Bandy OL, Rodolfo KS (1964) Distribution of foraminifera and sediments, Peru-Chile Trench area. Deep-Sea Res 11: $817-837$

Bender H. (1995) Test structure and classification in agglutinated foraminifera. In: Kaminski MA, Geroch S, Gasiński MA (eds) Proc 4th Int Workshop Agglutinated Foraminifera, Kraków, Poland, September 12-19, 1993. Grzybowski Foundation, Krakow, Special Publication no. 3, p 27-70

Bernhard JM (1993) Benthic foraminiferal distribution and biomass related to pore-water oxygen content: central California continental slope and rise. Deep-Sea Res 29:585-605

Bernhard JM, Sen Gupta BK (1999) Foraminifera in oxygendepleted environments. In: Sen Gupta BK (ed) Modern Foraminifera. Kluwer Academic Publishers, Dordrecht, p 201-216

Bett BJ (1999) RRS Charles Darwin Cruise 112C 19 May-24 June 1998. Atlantic margin environmental survey: seabed survey of deep-water areas (17th round tranches) to the north and west of Scotland. Southampton Oceanography Centre Cruise Report No. 25, p 171

Bett BJ (2001) UK Atlantic margin environmental survey: introduction and overview of bathyal benthic ecology. Cont Shelf Res 21:917-956

Bett BJ, Gooday AJ, Lamont P (1999) The xenophyophore Syringammina fragilissima Brady, 1883: rediscovered on the UK continental margin. Deep-Sea Newsl 28:9-11

Bett BJ, Billett DSM, Masson DG, Tyler PA (2001) RRS Discovery Cruise 248, 07 Jul-10 Aug 2000: a multidiscipli- 
nary study of the environment and ecology of deep-water coral ecosystems and associated seabed facies and features (The Darwin Mounds, Porcupine Bank and Porcupine Seabight). Southampton Oceanography Centre Cruise Report No. 36, p 108

Bowser SS Travis JL (2000) Methods for structural studies of reticulopodia, the vital foraminiferal 'soft part'. Micropaleontol 46(Suppl 1):47-56

Brady HB (1882) Report on the Foraminifera. Proc R Soc Edinb Sect B 11:708-717

Brady HB (1883) Syringammina, a new type of arenaceous Rhizopoda. Proc R Soc Lond Ser B 35:155-161

Carpenter WB (1868) Preliminary report of dredging operations in the seas to the north of the British Isles, carried out in Her Majesty's steam-vessel 'Lightning' by Dr Carpenter and Dr Wyville Thomson. Proc R Soc Lond Ser B 17:168-197

Carpenter WB, Jeffreys JG, Thomson W (1870) Preliminary report of the scientific exploration of the deep sea in H.M. surveying-vessel 'Porcupine', during the summer of 1862. Proc R Soc Lond Ser B 18:397-453

Cartwright NG, Gooday AJ, Jones AR (1989) The morphology, internal organization, and taxonomic position of Rhizammina algaeformis Brady, a large, agglutinated, deep-sea foraminifer. J Foraminiferal Res 19:115-125

Christiansen BO (1971) Notes on the biology of foraminifera. Troisième Symposium Européen de Biologie Marine. Vie Milieu 2(Suppl 2):465-478

Christie WW (1982) Lipid analyses, 2nd edn. Pergamon Press, Oxford

Corliss BH (1985) Microhabitats of deep-sea foraminifera within deep-sea sediments. Nature 314:435-438

de Folin L (1886) Les Bathysiphons: première pages d'une monographie du genre. Actes de les Société Linnéenne de Bordeaux 40:271-289

de Long EF, Yayanos AA (1985) Adaptation of the membrane lipids of a deep-sea bacterium to changes in hydrostatic pressure. Science 228:1101-1102

Fang J, Comet P, Brooks JM, Wadw TL (1993) Nonmethyleneinterrupted fatty acids of hydrocarbon seep mussels: occurrence and significance. Comp Biochem Physiol B 104: 287-291

Fenchel T (1969) The ecology of marine microbenthos. IV. Structure and function of the benthic ecosystem, its chemical and physical factors and the microfaunal communities with special reference to the ciliated protozoa. Ophelia 6: $1-182$

Fenchel T (1987) Ecology of Protozoa. The biology of freeliving phagotrophic protists. Springer-Verlag, Berlin

Fenchel T, Jansson BT (1966) On the vertical distribution of the microfauna in the sediments of a brackish-water beach. Ophelia 3:161-177

Fileman TW, Pond DW, Barlow RG, Mantoura RFC (1998) Vertical profiles of pigments, fatty acids and amino acids: evidence for undegraded diatomaceous material sedimenting to the deep ocean in the Bellingshausen Sea, Antarctica. Deep-Sea Res I 45:333-346

Folch JN, Lees N, Sloan-Stanley GH (1957) A simple method for the isolation and purification of total lipid. J Biol Chem 226:497-509

Fontanier C, Jorissen FJ, Licari L, Alexandre A, Anschutz P, Carbonel P (2002) Live benthic foraminiferal faunas from the Bay of Biscay: faunal density, composition, and microhabitats. Deep-Sea Res I 49:751-785

Fullarton JG, Dando PR, Sargent JR, Southward AJ, Southward EC (1995) Fatty acids of hydrothermal vent Ridgeia piscesae and inshore bivalves containing symbiotic bacteria. J Mar Biol Assoc UK 75:455-468
Ginger ML, Billett DS, Mackenzie KL, Konstandinos K and 5 others (2001) Organic matter assimilation and selective feeding by holothurians in the deep sea: some observations and comments. Prog Oceanogr 50:407-421

Goldstein ST (1999) Foraminifera: a biological overview. In: Sen Gupta BK (ed) Modern Foraminifera. Kluwer Academic Publishers, Dordrecht, p 37-55

Goldstein ST, Corliss BH (1994) Deposit feeding in selected deep-sea and shallow-water benthic foraminifera. DeepSea Res I 41:229-241

Gooday AJ (1988) The genus Bathysiphon (Protista, Foraminiferida) in the NE Atlantic: revision of some species described by de Folin (1886). J Nat Hist 22:71-93

Gooday AJ (1990) Recent deep-sea agglutinated Foraminifera: a brief review. In: Hemleben C, Kaminski MA, Kuhnt W, Scott DB (eds) Paleoecology, biostratigraphy, paleoceanography and taxonomy of agglutinated foraminifera. NATO ASI Series C: Mathematical and Physical Sciences, Vol 327. Kluwer, Dordrecht, p 271-304

Gooday AJ, Claugher D (1989) The genus Bathysiphon (Protista, Foraminiferida) in the NE Atlantic: SEM observations on the wall structure of seven species. J Nat Hist 23: 591-611

Gooday AJ, Turley CM (1990) Responses by benthic organisms to inputs of organic material to the ocean floor: a review. Philos Trans R Soc Lond A 331:119-138

Gooday AJ, Levin LA, Thomas CL, Hecker B (1992a) The distribution and ecology of Bathysiphon filiformis Sars and B. major de Folin (Protista, Foraminiferida) on the continental slope off North Carolina. J Foraminiferal Res 22: 129-146

Gooday AJ, Levin LA, Linke P, Heeger T (1992b) The role of benthic foraminifera in deep-sea food webs and carbon cycling. In: Rowe GT, Pariente V (eds) Deep-sea food chains and the global carbon cycle. Kluwer, Dordrecht, p 63-91

Gooday AJ, Shires R, Jones AR (1997) Large deep-sea agglutinated foraminifera: two differing kinds of organisation and their possible ecological significance. J Foraminiferal Res 27:278-291

Gooday AJ, Bernhard JM, Levin LA, Suhr SB (2000) Foraminifera in the Arabian Sea oxygen minimum zone and other oxygen deficient settings: taxonomic composition, diversity, and relation to metazoan faunas. Deep-Sea Res II 47 : $25-54$

Gooday AJ, Hughes JA, Levin LA (2001) The foraminiferan macrofauna from three North Carolina (U.S.A.) slope sites with contrasting carbon flux: a comparison with the metazoan macrofauna. Deep-Sea Res I 48:1709-1739

Goulder R (1971) Vertical distribution of some ciliated protozoa in two freshwater sediments Oikos 22:199-203

Graeve M, Kattner G, Piepenburg D (1997) Lipids in Arctic benthos: does the fatty acid and alcohol composition reflect feeding and trophic interactions? Polar Biol 18: 53-61

Gross O (1998) Investigation on autecology, migration and bioturbation of living benthic deep-sea Foraminifera (Protozoa). Ber Zent Meeres-Klimaforsch Univ Hambg E 15: 224

Gross O (2000) Influence of temperature, oxygen and food availability on the migrational activity of bathyal benthic foraminifera: evidence by microcosm experiments. Hydrobiologia 426:123-137

Hannah F, Rogerson A (1997) The temporal and spatial distribution of foraminiferans in marine benthic sediments of the Clyde Sea area, Scotland. Estuar Coast Shelf Sci 44: $377-383$ 
Heeger T (1990) Elektronenmikroskopische Untersuchungen zur Ernährungsbiologie benthischer Foraminiferen. Ber Sonderforschungsbereich 313(21):1-139

Heinz P (1999) Response of deep-sea benthic foraminifera to simulated phytodetritus pulses under laboratory conditions. Tübinger Mikropaläontolog Mitt 20:1-126

Hepburn L (2001) Assessment of the macrofaunal diversity associated with the cold-water coral, Lophelia pertusa at the Darwin Mounds, Rockall Trough. MSc thesis, University of Aberdeen

Herb R (1971) Distribution of recent benthonic foraminifera in the Drake Passage. In: Llano GA, Wallen IE (eds) Biology of Antarctic Seas IV. Antarctic Research Series 17. American Geophysical Union, Washington, DC, p 251-300

Hessler RR, Jumars PA (1974) Abyssal community analysis from replicate box cores in the central North Pacific. Deep-Sea Res 21:185-209

Holliday, NP, Pollard RT, Read JF, Leach H (2000) Water mass properties and fluxes in the Rockall Trough. Deep-Sea Res I 47:1303-1332

Jannink NT, Zachariasse WJ, Van der Zwaan GJ (1998) Living (Rose Bengal stained) benthic foraminifera from the Pakistan continental margin (northern Arabian Sea). Deep-Sea Res I 45:1483-1513

Jorissen F (1999) Benthic foraminiferal microhabitats below the sediment-water interface. In: Sen Gupta BK (ed) Modern Foraminifera. Kluwer Academic Publishers, Dordrecht, p 161-179

Jorissen F, Wittling I, Peypouquet JP, Rabouille C, Relexans JC (1998) Live benthic foraminiferal faunas off Cap Blanc, NW Africa: community structure and microhabitats. DeepSea Res I 45:2157-2188

Kiriakoulakis K, Bett BJ, Wolff GA (2000) Biogeochemistry of the Darwin Mounds - first results. Abstract, European Union of Geosciences. Cambridge Publications, Cambridge, p 4-6, Abstr. no. 751

Kitazato H, Ohga T (1995) Seasonal changes in deep-sea benthic foraminiferal populations: results of long-term observations at Sagami Bay, Japan. In: Sakai H, Nozaki Y (eds) Biochemical processes and ocean flux in the western Pacific. Terra Scientific Publishing Company (TERRAPUB), Tokyo, p 331-342

Kitazato H, Shirayama Y, Nakatsuka T, Fujiwara S and 7 others (2000) Seasonal phytodetritus deposition and responses of bathyal benthic foraminiferal populations in Sagami Bay, Japan: preliminary results from 'Project Sagami 1996-1999. Mar Micropaleontol 40:135-149

Köster M, Meyer-Reil LA (2001) Concentration and microbial decomposition of organic material in sediments of the Norwegian-Greenland Sea. In: Schäfer P, Ritzrau W, Schlüter M, Thiede J (eds) The Northern North Atlantic: a changing environment. Springer-Verlag, Berlin, p 241-257

Lee JJ (1980) Nutrition and physiology of the foraminifera. In: Levandowsky M, Hutner S (eds) Biochemistry and physiology of Protozoa, Vol 3. Academic Press, New York, p 43-66

Lee JJ (1993) 'On a piece of chalk' - updated. J Eukaryot Microbiol 40:395-410

Lee JJ, Muller WA (1973) Trophic dynamics and niches of salt marsh foraminifera. Am Zool 15:215-223

Levin LA (1991) Interactions between metazoans and large, agglutinated protozoans: implications for the community structure of deep-sea benthos. Am Zool 31:886-900

Levin LA, Childers SE, Smith CR (1991) Epibenthic, agglutinating foraminiferans in the Santa Catalina Basin and their response to disturbance. Deep-Sea Res 38:465-483

Levin LA, Blair NE, Martin CM, De Master DJ, Plaia G,
Thomas CJ (1999) Macrofaunal processing of phytodetritus on the Carolina margin: in situ experiments using ${ }^{13}$ C-labled diatoms. Mar Ecol Prog Ser 182:37-54

Linke P (1992) Metabolic adaptations of deep-sea benthic foraminifera to seasonally varying food input. Mar Ecol Prog Ser 81:51-63

Linke P, Altenbach AV, Graf G, Heeger T (1995) Response of deep-sea benthic foraminifera to a simulated sedimentation event. J Foraminiferal Res 25:75-82

Lipps JH (1983) Biotic interactions in benthic foraminifera. In: Tevesz MJS, McCall PL (eds) Biotoic interactions in recent and fossil benthic communities. Plenum Publishing, New York, p 331-376

Lipps JH, Valentine JW (1970) The role of foraminifera in the trophic structure of marine communities. Lethaia 3 : 279-286

Masson DG, Bett BJ, Billett DSM, Jacobs CL, Wheeler AJ, Wynn RB (in press) A fluid escape origin for deepwater coral-topped mounds in the northern Rockall Trough, NE Atlantic. Mar Geol

Meyer-Reil LA, Köster M (1991) Fine-scale distribution of hydrolytic activity associated with foraminiferans and bacteria in deep-sea sediments of the Norwegian-Greenland Sea. Kiel Meeresforsch Sonderh 8:121-126

Miller W (1988) Giant Bathysiphon (Foraminiferida) from Cretaceous turbidites, northern California. Lethaia 21: 363-374

Miller W (1995) Examples of Mesozoic and Cenozoic Bathysiphon (Foraminifera) from the Pacific rim and the taxonomic status of Terebellina Ulrich, 1904. J Paleontol 69: $624-634$

Moodley L, Hess C (1992) Tolerance of infaunal benthic foraminifera for low and high oxygen concentrations. Biol Bull (Woods Hole) 183:94-98

Moodley L, Boschker HTS, Middelburg JJ, Pel R, Herman PMJ, de Deckere E, Heip CHR (2000) Ecological significance of benthic foraminifera: ${ }^{13} \mathrm{C}$ labelling experiments. Mar Ecol Prog Ser 202:289-295

Moodley L, Middelburg JJ, Boschker HTS, Duineveld GCA Pel R, Herman PMJ, Heip CHR (2002) Bacteria and Foraminifera: key players in a short-term deep-sea benthic response to phytodetritus. Mar Ecol Prog Ser 236:23-29

Murray JW, Taplin CM (1984) Larger agglutinated foraminifera from the Faroe Channel and Rockall Trough collected by W. B. Carpenter. J Micropalaeontol 3:59-62

Muller WA (1975) Competition for food and other nicherelated studies of three species of salt-marsh foraminifera. Mar Biol 31:339-351

Muller WA, Lee JJ (1969) Apparent indispensability of bacteria in foraminiferan nutrition. J Protozool 16:471-478

Pearcey FG (1890) Notes on the foraminifera of the Faroe Channel and Wyville Thomson Ridge, with a description of a new species of Hyperammina. Trans Nat Hist Soc Glasgow 2:163-179

Pond DW, Dixon DR, Bell MV, Fallick AE, Sargent JR (1997a) Occurrence of $16: 2(n-4)$ and 18:2(n-4) fatty acids in the lipids of the hydrothermal vent shrimps Rimicaris exoculata and Alvinocaris markensis: nutritional and trophic implications. Mar Ecol Prog Ser 156:167-174

Pond DW, Segonzac M, Bell MV, Dixon DR, Fallick AE, Sargent JR (1997b) Lipid and lipid carbon stable isotope composition of the hydrothermal vent shrimp Mirocaris fortunata: evidence for nutritional dependence on photosynthetically-fixed carbon. Mar Ecol Prog Ser 157:221-231

Pond DW, Bell MV, Dixon DR, Fallick AE, Segonzac M, Sargent JR (1998) Stable carbon isotope composition of fatty acids in hydrothermal vent mussels containing methan- 
otrophic and thiotrophic bacterial endosymbionts. Appl Environ Microbiol 64:370-375

Pond DW, Gebruk A, Southward EC, Southward AJ, Fallick AE, Bell MV, Sargent JR (2000) Unusual fatty acid composition of storage lipids in the bresilioid shrimp Rimicaris exoculata couples the photic zone with MAR hydrothermal vent sites. Mar Ecol Prog Ser 198:171-179

Rice AL (1986) British oceanographic vessels 1800-1950. The Ray Society, London

Rivkin RB, DeLaca TE (1990) Trophic dynamics in Antarctic benthic communities. I. In situ ingestion of microalgae by Foraminifera and metazoan meiofauna. Mar Ecol Prog Ser 64:129-136

Roberts JM, Harvey SM, Lamont PA, Gage JD, Humphery JD (2000) Seabed photography, environmental assessment and evidence for deep-water trawling on the continental margin west of the Hebrides. Hydrobiologia 441:173-183

Russell NJ, Nichols DS (1999) Polyunsaturated fatty acids in marine bacteria - a dogma rewritten. Microbiology 145: $767-779$

Sargent JR, Parkes RJ, Mueller-Harvey I, Henderson RJ (1987) Lipid biomarkers in marine ecology. In: Sleigh MA (ed) Microbes in the sea. Ellis Horwood, Chichester, p 119-138

Schiebel R (1992) Rezente benthische Foraminiferen in Sedimenten des Schelfes und oberen Kontinentalhanges im Golf von Guinea (Westafrika). Berichte-Reports, GeolPaläont Inst Univ Kiel 51:179

Schmiedl G, de Bovée F, Buscail R, Charrière B, Hemleben C, Medernach L, Picon P (2000) Trophic control of benthic foraminiferal abundance and microhabitat in the bathyal Gulf of Lions, western Mediterranean Sea. Mar Micropalaeontol 40:167-188

Schönfeld J (2001) Benthic foraminifera and pore-water oxy-

Editorial responsibility: Lisa Levin (Contributing Editor), La Jolla, California, USA gen profiles: a re-assessment of species boundary conditions at the Western Iberian margin. J Foraminiferal Res 31:86-107

Scott CL, Falk-Petersen S, Sargent JR, Hop H, Loenne OJ, Poltermann M (1999) Lipids and trophic interactions of ice fauna and pelagic zooplankton in the marginal ice zone of the Barents Sea. Polar Biol 21:65-70

Severin KP (1987) Laboratory observations of the rate of subsurface movement of a small miliolid foraminifer. J Foraminiferal Res 17:110-116

Severin KP, Erskian MG (1981) Laboratory experiments on the vertical movement of Quinqueloculina impressa Reuss through sand. J Foraminiferal Res 11:133-136

Tendal OS, Hessler RR (1977) An introduction to the biology and systematics of Komokiacea. Galathea Rep 14:165-194

Timm S (1992) Rezente Tiefsee-Benthosforaminiferen aus Oberflächen-Sedimenten des Golfes von Guinea (Westafrika)-Taxonomie, Verbreitung, Ökologie und Korngrößenfraktionen. Berichte-Reports, Geol-Paläont Inst Univ Kiel 51:192

Travis JL, Bowser SS (1991) The mobility of foraminifera. In: Lee JJ, Anderson OR (eds) Biology of Foraminifera. Academic Press, London, p 91-155

Turley CM, Gooday AJ, Green JC (1993) Maintenance of abyssal benthic foraminifera under high pressure and low temperature: some preliminary results. Deep-Sea Res I 40:643-652

Van der Zwaan GJ, Duijnstee IAP, den Dulk M, Ernst SR, Jannink NT, Kouwenhoen TJ (1999) Benthic foraminifers: proxies or problems? A review of paleoecological concepts. Earth Sci Rev 46:213-236

Zhukova NV (1991) The pathway of the biosynthesis of nonmethylatene-interrupted dienoic fatty acids in molluscs. Comp Biochem Physiol B 100:801-804

Submitted: January 17, 2002; Accepted: August 16, 2002 Proofs received from author(s): November 21, 2002 